\title{
Transition of a vestibular schwannoma to a malignant peripheral nerve sheath tumor with loss of H3K27 trimethylation after radiosurgery - a case report and review of the literature
}

\author{
Felix Behling ${ }^{1,2}\left(\mathbb{D} \cdot\right.$ Imane Bersali $^{1} \cdot$ Antonio Santacroce $^{3} \cdot$ Johann Hempel $^{2,4} \cdot$ Kosmas Kandilaris $^{2,5}$. \\ Jens Schittenhelm ${ }^{2,5}$ (D) Marcos Tatagiba ${ }^{1,2}$
}

Received: 24 May 2021 / Revised: 17 July 2021 / Accepted: 30 July 2021 / Published online: 15 August 2021

(c) The Author(s) 2021, corrected publication 2022

\section{Introduction}

Vestibular schwannomas (VS) are benign slow-growing tumors arising from the vestibular nerve and are the most common intracranial nerve sheath tumors [1]. Nonetheless, due to the location in the internal auditory canal and the cerebellopontine angle, several neurovascular structures are at risk with tumor progression. Through microsurgical resection under intraoperative neuromonitoring in specialized skull base centers, most VS can be safely resected [2, $3]$. As an alternative treatment, radiation therapy and radiosurgery have produced good tumor control rates for smaller vestibular schwannomas [4]. However, like microsurgery, radiation is not without risk. Besides the risk of radiotoxicity to cranial nerves and the brainstem [5], malignant transformation after radiotherapy has been described in several cases [6-8]. We now present a case of a vestibular schwannoma that received multimodal treatments including two sessions of gamma knife radiosurgery and transformed into a malignant peripheral nerve sheath tumor (MPNST). The clinical course as well as the histopathological evaluation is described together with a review of the current literature.

Felix Behling

felixbehling@yahoo.de

1 Department of Neurosurgery, Eberhard-Karls University of Tübingen, Hoppe-Seyler Street 3, 72076 Tübingen, Germany

2 Comprehensive Cancer Center Tübingen, Eberhard-Karls University, Tübingen, Germany

3 Department of Neurosurgery, St. Barbara-Klinik Hamm-Heessen, Hamm, Germany

4 Department of Diagnostic and Interventional Neuroradiology, Eberhard-Karls University, Tübingen, Germany

5 Department of Neuropathology, Eberhard-Karls University, Tübingen, Germany

\section{Clinical summary}

A 29-year-old woman was diagnosed with a right sided vestibular schwannoma due to progressive right-sided tinnitus and dizziness. The initial size was T3a according to the Hannover classification (Fig. 1A and B). Tumor growth was observed during the following 4 years (Fig. 1C and D) and the first treatment was performed with gamma knife radiosurgery at the age of 33 . The target margin dose was $12 \mathrm{~Gy}$ to a $50 \%$ Isodose line covering a target volume of $1,3 \mathrm{cc}$. In the following months, the patient reported only an increase in tinnitus and in the further course also suffered dizziness and neuralgia in the territory of I and II right trigeminal branches that partially improved with Pregabalin. Further tumor progression was seen and the patient underwent partial resection at the age of 35 . She required transient ventricular drainage on 08/21/13 due to post-operative bleeding that caused moderate obstruction of the IV ventricle with hydrocephalus. No shunt placement was necessary. The patient was referred to treatment with Gamma Knife radiosurgery for the residual schwannoma.

At the time or retreatment, the patient showed hypoesthesia in the territory of the right trigeminal III branch, right masseter paresis and pain in the glossopharyngeal territory on right-sided corneal stimulation. The remaining neurological examination, including confrontational campimetry and fundus examination, was normal. The maximum dose achieved of the second radiosurgery treatment was $20.8 \mathrm{~Gy}$ with a coverage dose of $12.5 \mathrm{~Gy}$ in the $60 \%$ isodose. Critical structures were considered. The right facial nerve received a dose lower than $9 \mathrm{~Gy}$, the right trigeminal nerve a coverage dose and the brain stem a dose lower than $10 \mathrm{~Gy}$ (receiving a dose $>8$ Gy in a volume of $0.09 \mathrm{cc}$ and a dose $>5 \mathrm{~Gy}$ in a volume of $0.05 \mathrm{cc}$ ). The volume of tissue included within the coverage isodose was $0.823 \mathrm{cc}$. 
Fig. 1 MR-images throughout the disease course showing the extent of the tumor prior to the first treatment with gamma knife ( $\mathbf{A}$ and $\mathbf{B}$ ) and further tumor growth 2 years later $(\mathbf{C}$ and D). Subsequently, the tumor was partially resected and after further growth a second round of gamma knife was applied. Afterwards, the tumor showed further progression ( $\mathbf{E}$ and $\mathbf{F}$ ) and gross total resection was done ( $\mathbf{G}$ and $\mathbf{H})$. Two years later, another tumor recurrence occurred ( $\mathbf{I}$ and $\mathbf{J}$ ) prompting another gross total resection now revealing the histology of a MPNST (K and $\mathbf{L})$. Besides all efforts, the tumor showed a massive progression (M) and the patient deceased shortly afterwards

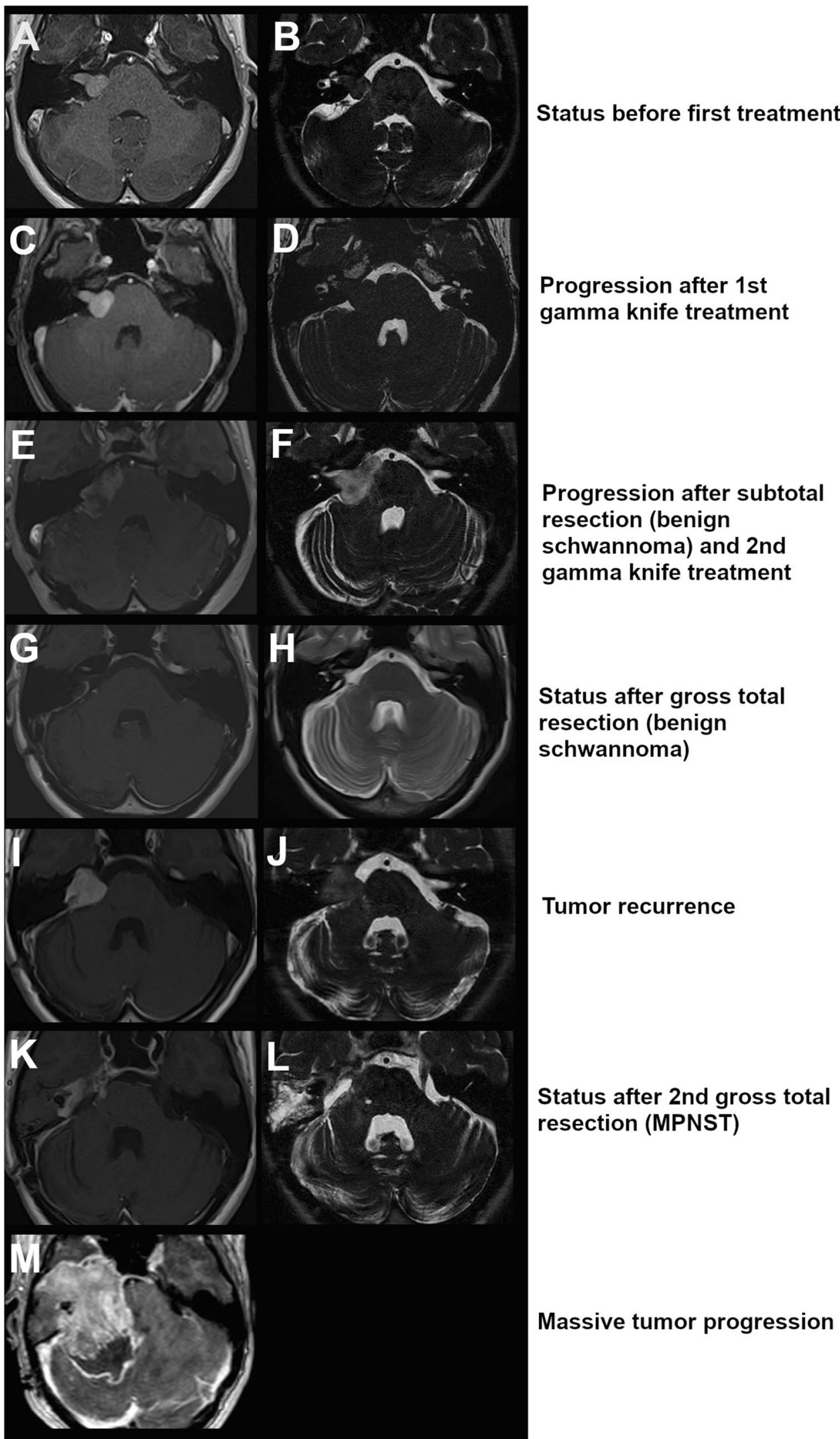


At the age of 39, the patient presented to our department with complete right-sided hearing loss, trigeminal neuralgia, periorbital spasm as well as balance disorders and mild dysphagia. The tumor had progressed to a $\mathrm{T} 4 \mathrm{a}$ vestibular schwannoma (Fig. 1E and F). Gross total microsurgical resection was done with functional perseveration of the facial nerve with a postoperative facial palsy House \& Brackmann grade III (Fig. 1G and H). The histopathology revealed a common schwannoma WHO grade I (Fig. 2A and B). Two years later at the age of 41 , the patient presented to our department with another tumor recurrence which showed atypical imaging features (Fig. 1I and J). A change in histopathology towards malignant transformation was suspected and open microsurgical inspection and sampling offered. During surgery, severe adhesions of the tumor to the facial nerve were observed and biopsy showed a schwannoma WHO grade I (Fig. 2C and D). Due to further rapid growth within 8 months, radical surgical resection of the tumor including the infiltrated facial nerve with facial reconstruction was planned. During surgery infiltration of the brain stem was observed and another gross total resection was achieved (Fig. 1K and L). Now the histopathological evaluation showed the diagnosis of a malignant peripheral nerve sheath tumor (MPNST, Fig. 2E-G). Two days after surgery, a localized hematoma in the resection cavity was evacuated. The patient recovered quickly and was discharged one week after the revision surgery with a Karnofsky Performance Score of $80 \%$. The case was presented and discussed in our neurooncological tumor board and the sarcoma board. Adjuvant radiation was recommended. Four months later, a massive tumor progression with rapid clinical decline occurred (Fig. 1M) and the patient died shortly afterwards at the age of 42. The disease course is summarized in Fig. 3

\section{Pathology findings}

In the initial resection specimen, we observed the typical histology of a conventional schwannoma with a biphasic architecture consisting of moderately cellular, compact Antoni A regions alternating with loosely arranged Antoni B areas in roughly equal proportions. There were no discernible atypical features with tumor cells showing normochromatic elongated tapered nuclei with retained expression of H3(K27me3) (Fig. 2A and B).

Microscopic assessment of small tissue fragments from the recurrent tumour 2 years later revealed a similar blunt schwannoma histopathology with only minimal proliferative activity and retained nuclear positivity for H3(K27me3) (Fig. 2C and D).

In the latest radical resection specimen 8 months afterwards, we observed a highly cellular spindle cell tumour with a hemangiopericytoma-like vascular pattern and a vaguely fascicular architecture. In certain areas, intraluminal vascular herniation of the tumour cells could be identified. The neoplastic cells manifested moderate atypia und increased proliferation with abundant mitotic figures corresponding to a high-grade malignant peripheral nerve sheath tumor (Fig. 2E and F). Sparse residual tissue of the original benign schwannoma was focally discernible. Immunohistochemistry revealed a complete loss of immunoreactivity for $\mathrm{H} 3(\mathrm{~K} 27 \mathrm{me} 3)$ in the neoplastic nuclei (Fig. 2G). An extensive negativity for S-100 and a nuclear accumulation of p53 could also be identified. An antibody stain against neurofilament revealed numerous entrapped nerve fibers consistent with an infiltrative growth pattern.

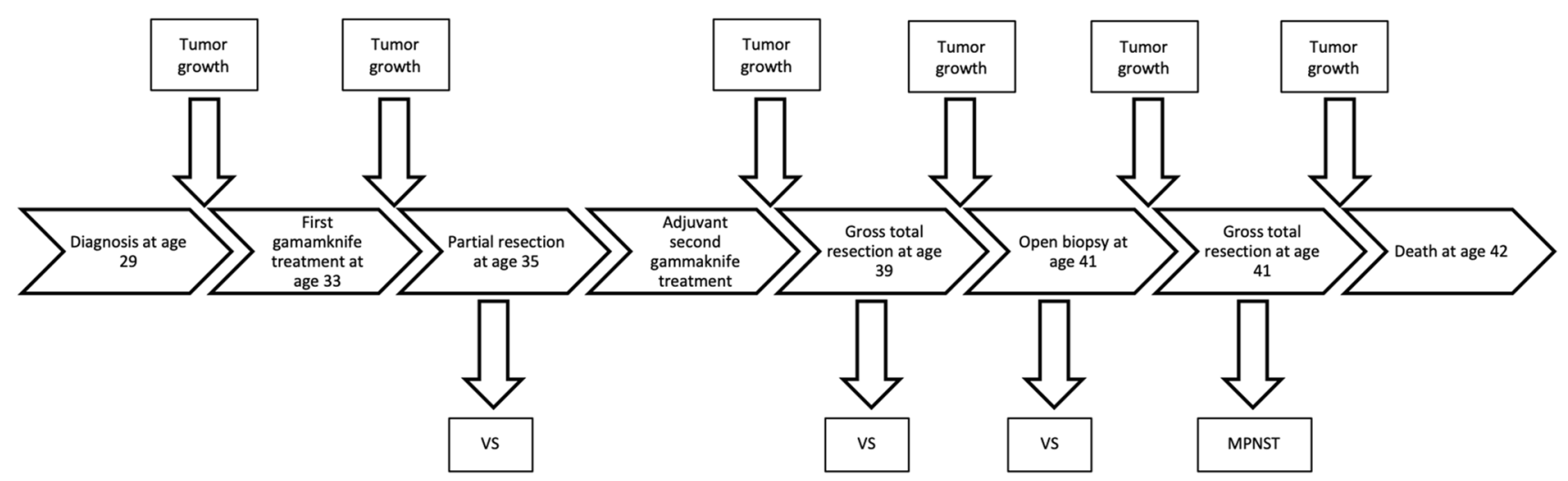

Fig. 2 The histopathological images show the recurrent schwannoma after the gross total resection in our center as a moderately cellular spindle cell tumor without signs of atypia (A) and retained nuclear expression of H3K27me3 (B) (magnification $100 \times$. A biopsy of the next recurrence 2 years later revealed again a schwannoma. A spindle cell tumor of moderate cellularity consisting of plump neoplastic cells again with retained nuclear expression of $\mathrm{H} 3 \mathrm{~K} 27 \mathrm{me} 3$ was seen $(\mathbf{C}$ and $\mathbf{D})$ (magnification $100 \times$ ). After the second gross total resection, we observed a highly cellular tumor of moderately atypical cells with signs of intraluminal vascular herniation (E, magnification $200 \times$ ) and several mitotic figures (F, magnification $400 \times$ ). Now, loss of nuclear expression of $\mathrm{H} 3 \mathrm{~K} 27 \mathrm{me} 3$ in the tumor cells was detected, with positive endothelial cells, which served as an internal control $(\mathrm{G}$, magnification $400 \times$ ) 
Fig. 3 Timeline summarizing the course of disease and treatment
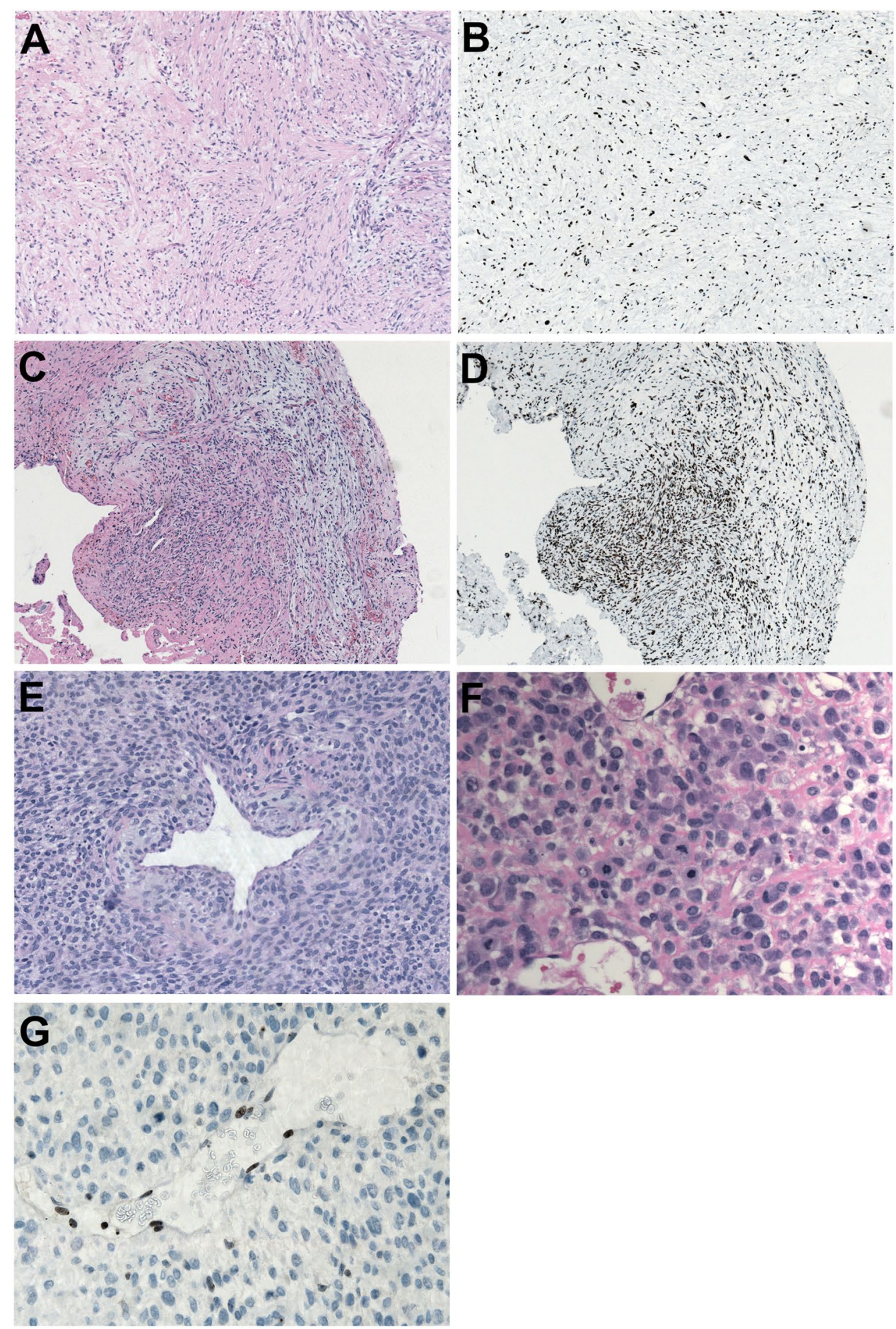

\section{Discussion}

Schwannomas are typically encapsulated tumor consisting of well-differentiated Schwann cells with Merlin or SMARCB1 inactivation [9]. Cellular schwannomas are well-known variants and their hypercellularity and loss of rhythmic growth pattern must not be confused with true malignancy [10]. The transformation of a vestibular schwannoma into a malignant peripheral nerve sheath tumor after radiosurgery has been described in several cases before, as listed in Table 1. On the contrary, two cases of spontaneous malignant transformation without irradiation from benign schwannoma to malignant peripheral verve sheath tumor have also been reported [11-13]. Therefore, role of radiation therapy in malignant progression has been argued [14]. Overall, the mechanism of malignant transformation remains unclear, but it is important 
Table 1 List of reported vestibular schwannomas with malignant transformation in the literature with corresponding clinical data

\begin{tabular}{|c|c|c|c|c|c|c|c|c|}
\hline Author,year & Age,Sex & NF2 & $1^{\text {st }}$ treatment & RTx & Marginal dose (Gy) & Latency (y) & $2^{\text {nd }}$ pathology & Survival (m) \\
\hline Comey, 1998 & $44, \mathrm{M}$ & $\mathrm{N}$ & RTx & GK & 14.4 & 5.5 & MTT & 12 \\
\hline Noren, 1998 & $18, \mathrm{~F}$ & $\mathrm{Y}$ & RTx & GK & 20 & 5 & MTT & $\mathrm{n} / \mathrm{a}$ \\
\hline Pollock, 1998 & $\mathrm{n} / \mathrm{a}$ & $\mathrm{n} / \mathrm{a}$ & $\mathrm{RTx}$ & GK & 16 & 7 & MTT & $\mathrm{n} / \mathrm{a}$ \\
\hline Thomsen, 2000 & $19, \mathrm{~F}$ & $\mathrm{Y}$ & RTx & GK & 12 & 6 & Sarcoma & 24 \\
\hline \multirow[t]{3}{*}{ Baser 2000} & $\mathrm{n} / \mathrm{a}$ & $\mathrm{Y}$ & RTx & $\mathrm{n} / \mathrm{a}$ & $\mathrm{n} / \mathrm{a}$ & $\mathrm{n} / \mathrm{a}$ & MPNST & $\mathrm{n} / \mathrm{a}$ \\
\hline & $\mathrm{n} / \mathrm{a}$ & $\mathrm{Y}$ & RTx & $\mathrm{n} / \mathrm{a}$ & $\mathrm{n} / \mathrm{a}$ & $\mathrm{n} / \mathrm{a}$ & MPNST & $\mathrm{n} / \mathrm{a}$ \\
\hline & $\mathrm{n} / \mathrm{a}$ & $\mathrm{Y}$ & RTx & $\mathrm{n} / \mathrm{a}$ & $\mathrm{n} / \mathrm{a}$ & $\mathrm{n} / \mathrm{a}$ & MPNST & $\mathrm{n} / \mathrm{a}$ \\
\hline Hanabusa, 2001 & $51, \mathrm{~F}$ & $\mathrm{~N}$ & $\mathrm{~S}$ & GK & $15+14$ & 0.5 & Sarcoma & 4 \\
\hline Bari, 2002 & $28, \mathrm{~F}$ & $\mathrm{Y}$ & RTx & GK & 15 & 4 & MPNST & 3 \\
\hline Shin, 2002 & $26, \mathrm{~F}$ & $\mathrm{~N}$ & $\mathrm{~S}$ & GK & 17 & 6 & MPNST & 10 \\
\hline Ho, 2002 & $14, \mathrm{~F}$ & $\mathrm{Y}$ & RTx & FRT & 18 & 0.6 & $\mathrm{n} / \mathrm{a}$ & 0.5 \\
\hline McEvoy, 2003 & $22, \mathrm{M}$ & $\mathrm{Y}$ & RTx & GK & 15 & 2 & $\mathrm{n} / \mathrm{a}$ & 3 \\
\hline Wilkinson, 2004 & $53, \mathrm{M}$ & $\mathrm{N}$ & $\mathrm{S}$ & $\mathrm{n} / \mathrm{a}$ & $\mathrm{n} / \mathrm{a}$ & 7 & MPNST & $\mathrm{n} / \mathrm{a}$ \\
\hline Muracciole, 2004 & $61, \mathrm{~F}$ & $\mathrm{~N}$ & RTx & GK & $10+12$ & 6 & MTT & $\mathrm{n} / \mathrm{a}$ \\
\hline Kubo, 2005 & $51, \mathrm{M}$ & $\mathrm{N}$ & $\mathrm{S}$ & GK & 14 & 0.7 & MPNST & 12 \\
\hline Hasegawa, 2005 & $56, \mathrm{~F}$ & $\mathrm{~N}$ & RTx & GK & 12.7 & 5.7 & MPNST & 12 \\
\hline $\begin{array}{l}\text { Maire, } 2006 \\
\text { Markou, } 2012\end{array}$ & $45, \mathrm{~F}$ & $\mathrm{~N}$ & $\mathrm{~S}$ & FRT & $\mathrm{n} / \mathrm{a}$ & 18 & MPNST & $\mathrm{n} / \mathrm{a}$ \\
\hline Van Rompaey, 2009 & $53, \mathrm{~F}$ & $\mathrm{~N}$ & $\mathrm{~S}$ & SRS & 12 & 8 & MPNST & $\mathrm{n} / \mathrm{a}$ \\
\hline Yang, 2010 & $74, \mathrm{M}$ & $\mathrm{N}$ & $\mathrm{S}$ & SRS & 12.5 & 6 & Sarcoma & 1 \\
\hline Dematriades, 2010 & $27, \mathrm{M}$ & $\mathrm{N}$ & $\mathrm{S}$ & GK & 15 & 10 & MPNST & 6 \\
\hline Akamatsu, 2010 & $67, \mathrm{~F}$ & $\mathrm{~N}$ & $\mathrm{~S}$ & GK & 12 & 7.5 & MPNST & $\mathrm{n} / \mathrm{a}$ \\
\hline Tanbouzi, 2011 & $15, \mathrm{M}$ & $\mathrm{Y}$ & RTx & GK & 13.5 & 5 & MPNST & 3 \\
\hline $\begin{array}{l}\text { Schmitt, } 2011 \\
\text { Milligan, } 2012\end{array}$ & $51, \mathrm{M}$ & $\mathrm{N}$ & RTx & GK & 12 & 7.5 & Sarcoma & 7 \\
\hline Puataweepong, 2012 & $34, \mathrm{~F}$ & $\mathrm{~N}$ & $\mathrm{~S}$ & FRT & $\mathrm{n} / \mathrm{a}$ & 6 & MPNST & $\mathrm{n} / \mathrm{a}$ \\
\hline Yanamadala, 2013 & $46, \mathrm{~F}$ & $\mathrm{~N}$ & $\mathrm{~S}$ & GK & 14 & 6 & MPNST & 12 \\
\hline Kuzmik, 2013 & $73, \mathrm{~F}$ & $\mathrm{~N}$ & RTx & SRS & 13 & 0.5 & MPNST & 2 \\
\hline Seferis, 2014 & $46, \mathrm{~F}$ & $\mathrm{~N}$ & $\mathrm{~S}$ & GK & 12 & 5.5 & MPNST & $\mathrm{n} / \mathrm{a}$ \\
\hline Se, 2016 & $49, \mathrm{~F}$ & $\mathrm{~N}$ & RTx & GK & 12.5 & 6 & Sarcoma & 6 (alive) \\
\hline Simmermacher, 2017 & $39, \mathrm{~F}$ & $\mathrm{~N}$ & RTx & FRT & $\mathrm{n} / \mathrm{a}$ & 13 & MPNST & $\mathrm{n} / \mathrm{a}$ \\
\hline Frischer, 2018 & $\mathrm{n} / \mathrm{a}$ & $\mathrm{N}$ & RTx & GK & 13 & 8 & MPNST & 9 \\
\hline Haq, 2019 & $54, \mathrm{M}$ & $\mathrm{N}$ & $\mathrm{S}$ & GK & 10 & 9 & MPNST & 9 (alive) \\
\hline Peker, 2019 & $40, \mathrm{~F}$ & $\mathrm{~N}$ & $\mathrm{~S}$ & CK & $\mathrm{n} / \mathrm{a}$ & $\mathrm{n} / \mathrm{a}$ & MPNST & $\mathrm{n} / \mathrm{a}$ \\
\hline Tish, 2019 & $65, \mathrm{~F}$ & $\mathrm{~N}$ & RTx & GK & 12 & 12 & MTT & 10 \\
\hline Boucher, 2020 & $66, \mathrm{~F}$ & $\mathrm{~N}$ & RTx & GK & 12.5 & 17 & Sarcoma & 7 \\
\hline \multirow[t]{2}{*}{ Sherry, 2020} & $28, \mathrm{~F}$ & $\mathrm{~N}$ & $\mathrm{~S}$ & SRS & $\mathrm{n} / \mathrm{a}$ & 15 & Sarcoma & $\mathrm{n} / \mathrm{a}$ \\
\hline & $68, \mathrm{M}$ & $\mathrm{Y}$ & RTx & GK & $\mathrm{n} / \mathrm{a}$ & 3 & MPNST & 12 \\
\hline Present case & $29, \mathrm{~F}$ & $\mathrm{~N}$ & RTx & GK & $\mathrm{n} / \mathrm{a}$ & $\mathrm{n} / \mathrm{a}$ & MPNST & 4 \\
\hline
\end{tabular}

$M$ male; $F$ female; NF2 neurofibromatosis type 2; $n / a$ not available; $S$ surgery; $R T x$ radiation therapy; $S R S$ stereotactic radiotherapy; $F R T$ fractionated radiotherapy; $G K$ gamma-knife radiosurgery; $C K$ cyber-knife radiosurgery; MTT malignant triton tumor; MPNST malignant peripheral nerve sheath tumor

to report every case to allow for a better understanding in the future.

In a series of $45 \mathrm{VS}$ treated with fractionated radiotherapy, malignant transformation was seen in a case after long follow up which prompted the authors to suggest cautious use of radiation in young patients [15]. The case currently presented was 29 years old at the time of diagnosis and 33 at the first radiosurgery treatment. Looking at all reported cases so far [6-8, 15-44] (Table 1) patients of all age groups seem to be able to develop an MPNST after radiation, but it is remarkable that 10 out of 30 cases with age information were younger than 30 (33.3\%). In comparison, the series of our department with 1381 vestibular schwannomas included only 202 patients of that age category $(14.6 \%)$. We recently 
showed in a retrospective analysis that younger patients, suffering from sporadic VS, had larger tumor volumes and higher volumetric tumor growth rates prior to surgery [45] suggesting that sporadic VS developing at a younger age may behave differently. Furthermore, a more cautious indication for radiosurgery for vestibular schwannomas in NF2 patients has already been suggested [8].

Overall, longer follow-ups of large case numbers treated with radiosurgery, that can be expected in the near future, will shed more light on this rare but severe complication and hopefully allow for a risk stratification before treatment.

What is special about this current case is the detailed information about the $\mathrm{H} 3 \mathrm{~K} 27$ trimethylation status over the disease course. The loss of the trimethylation of lysin 27 of histone 3 is an increasingly established marker for the differentiation of MPNSTs from other pathologies [46]. The immunohistochemical detection of the loss of H3K27me3 has also been shown to be a highly sensitive marker for radiation induced MPNSTs [47]. Furthermore, MPNST with H3K27me3 loss clearly show a unique methylation profile that is clearly distinct from conventional and cellular schwannoma [48]. In this current case, we documented the course of H3K27me3 status with malignant tumor transformation. While the trimethylation of $\mathrm{H} 3 \mathrm{~K} 27 \mathrm{me} 3$ was retained in the sample of the first gross total resection (Fig. 2B) and the subsequent biopsy that was done after further quick tumor progression (Fig. 2D), a clear H3K27me3 loss was detected in the last tumor sample that revealed the MPNST (Fig. 2G). Thus, the diagnostic role of H3K27me3 is likely transferrable to vestibular schwannomas, but may be influenced by tumor location, as $\mathrm{H} 3 \mathrm{~K} 27 \mathrm{me} 3$ seems to be retained in spinal MPNST [48]. Immortalized Schwann cells do not show any reduction in H3K27me3 expression [49]. However, there is currently no information about the distribution of histone methylations in VS [50]. Future studies of H3K27me in larger cohorts of vestibular schwannomas are warranted.

MPNST arise usually in the setting of plexiform neurofibromas in NF1. In this case, we did not have any evidence of hereditary NF1 disorder or histological criteria associated with atypical neurofibromatous neoplasms of uncertain biologic potential (ANNUBP) [51].

\section{Conclusion}

Malignant transformation of vestibular schwannoma to malignant peripheral nerve sheath tumor after radiation therapy is rare but fatal. Younger age seems to be a risk factor. The loss of the H3K27 trimethylation can be considered as a marker for malignant transformation of vestibular schwannoma.
Author contribution FB, AS, KK, JS, and MT have developed the conception of the work and drafted the manuscript. All authors were involved in the conception and design of the manuscript. JS and KK carried out the histopathological examinations. JH contributed the radiological analysis and images. Clinical data were gathered by FB and AS.

Data availability Not applicable.

Code availability Not applicable.

Funding Open Access funding enabled and organized by Projekt DEAL.

\section{Declarations}

Ethics approval Not applicable.

Consent for participation The informed consent for the scientific use of tissue and data was obtained from the patient.

Consent for publication The informed consent for the scientific use of tissue and data was obtained from the patient.

Conflict of interest The authors declare no competing interests.

Open Access This article is licensed under a Creative Commons Attribution 4.0 International License, which permits use, sharing, adaptation, distribution and reproduction in any medium or format, as long as you give appropriate credit to the original author(s) and the source, provide a link to the Creative Commons licence, and indicate if changes were made. The images or other third party material in this article are included in the article's Creative Commons licence, unless indicated otherwise in a credit line to the material. If material is not included in the article's Creative Commons licence and your intended use is not permitted by statutory regulation or exceeds the permitted use, you will need to obtain permission directly from the copyright holder. To view a copy of this licence, visit http://creativecommons.org/licenses/by/4.0/.

\section{References}

1. Ostrom QT, Patil N, Cioffi G, Waite K, Kruchko C, BarnholtzSloan JS (2020) CBTRUS Statistical Report: Primary Brain and Other Central Nervous System Tumors Diagnosed in the United States in 2013-2017. Neuro Oncol 22:iv1-iv96. https://doi.org/ 10.1093/neuonc/noaa200

2. Samii M, Gerganov V, Samii A (2006) Improved preservation of hearing and facial nerve function in vestibular schwannoma surgery via the retrosigmoid approach in a series of 200 patients. J Neurosurg 105:527-535. https://doi.org/10.3171/jns.2006.105.4.527

3. Starnoni D, Giammattei L, Cossu G, Link MJ, Roche PH, Chacko AG, Ohata K, Samii M, Suri A, Bruneau M, Cornelius JF, Cavallo L, Meling TR, Froelich S, Tatagiba M, Sufianov A, Paraskevopoulos D, Zazpe I, Berhouma M, Jouanneau E, Verheul JB, Tuleasca C, George M, Levivier M, Messerer M, Daniel RT (2020) Surgical management for large vestibular schwannomas: a systematic review, meta-analysis, and consensus statement on behalf of the EANS skull base section. Acta Neurochir (Wien) 162:2595-2617. https://doi.org/10.1007/s00701-020-04491-7

4. Buss EJ, Wang TJC, Sisti MB (2020) Stereotactic radiosurgery for management of vestibular schwannoma: a short review. Neurosurg Rev. https://doi.org/10.1007/s10143-020-01279-2 
5. Azzam P, Mroueh M, Francis M, Daher AA, Zeidan YH (2020) Radiation-induced neuropathies in head and neck cancer: prevention and treatment modalities. Ecancermedicalscience 14:1133. https://doi.org/10.3332/ecancer.2020.1133

6. Boucher AB, Mendoza P, Neill SG, Eaton B, Olson JJ (2020) High-Grade Sarcoma Arising within a Previously Irradiated Vestibular Schwannoma: A Case Report and Literature Review. World Neurosurg 144:99-105. https://doi.org/10.1016/j.wneu.2020.08. 170

7. Seferis C, Torrens M, Paraskevopoulou C, Psichidis G (2014) Malignant transformation in vestibular schwannoma: report of a single case, literature search, and debate. J Neurosurg 121(Suppl):160-166. https://doi.org/10.3171/2014.7.GKS141311

8. Sherry AD, Bingham B, Kim E, Monsour M, Luo G, Attia A, Chambless LB, Cmelak AJ (2020) Secondary malignancy following stereotactic radiosurgery for benign neurologic disease: A cohort study and review of the literature. J Radiosurg SBRT 6:287-294

9. Vitte J, Gao F, Coppola G, Judkins AR, Giovannini M (2017) Timing of Smarcb1 and Nf2 inactivation determines schwannoma versus rhabdoid tumor development. Nat Commun 8:300. https:// doi.org/10.1038/s41467-017-00346-5

10. Pekmezci M, Reuss DE, Hirbe AC, Dahiya S, Gutmann DH, von Deimling A, Horvai AE, Perry A (2015) Morphologic and immunohistochemical features of malignant peripheral nerve sheath tumors and cellular schwannomas. Mod Pathol 28:187-200. https://doi.org/10.1038/modpathol.2014.109

11. Bashir A, Poulsgaard L, Broholm H, Fugleholm K (2016) Late malignant transformation of vestibular schwannoma in the absence of irradiation: case report. J Neurosurg 125:372-377. https://doi.org/10.3171/2015.6.JNS1544

12. Belyaev A, Usachev D, Shimansky V, Odamanov D, Shishkina L, Ryzhova M, Golanov A (2018) Spontaneous Transformation of Vestibular Schwannoma into Malignant Peripheral Nerve Sheath Tumor. Asian J Neurosurg 13:810-813. https://doi.org/10.4103/ ajns.AJNS_251_16

13. Carlson ML, Jacob JT, Habermann EB, Glasgow AE, Raghunathan A, Link MJ (2016) Malignant peripheral nerve sheath tumors of the eighth cranial nerve arising without prior irradiation. J Neurosurg 125:1120-1129. https://doi.org/10.3171/2015.7.JNS15 1056

14. Li J, Wang Q, Zhang M, Zhang G, Zhang S, Hui X (2021) Malignant Transformation in Vestibular Schwannoma: Clinical Study With Survival Analysis. Front Oncol 11:655260. https://doi.org/ 10.3389/fonc. 2021.655260

15. Maire JP, Huchet A, Milbeo Y, Darrouzet V, Causse N, Celerier D, Liguoro D, Bebear JP (2006) Twenty years' experience in the treatment of acoustic neuromas with fractionated radiotherapy: a review of 45 cases. Int J Radiat Oncol Biol Phys 66:170-178. https://doi.org/10.1016/j.ijrobp.2006.04.017

16. Akamatsu Y, Murakami K, Watanabe M, Jokura H, Tominaga $\mathrm{T}$ (2010) Malignant peripheral nerve sheath tumor arising from benign vestibular schwannoma treated by gamma knife radiosurgery after two previous surgeries: a case report with surgical and pathological observations. World Neurosurg 73:751-754. https:// doi.org/10.1016/j.wneu.2010.04.009

17. Bari ME, Forster DM, Kemeny AA, Walton L, Hardy D, Anderson JR (2002) Malignancy in a vestibular schwannoma. Report of a case with central neurofibromatosis, treated by both stereotactic radiosurgery and surgical excision, with a review of the literature. Br J Neurosurg 16:284-289. https://doi.org/10.1080/0268869022 0148888

18. Baser ME, Evans DG, Jackler RK, Sujansky E, Rubenstein A (2000) Neurofibromatosis 2, radiosurgery and malignant nervous system tumours. Br J Cancer 82:998. https://doi.org/10.1054/bjoc. 1999.1030
19. Comey CH, McLaughlin MR, Jho HD, Martinez AJ, Lunsford LD (1998) Death from a malignant cerebellopontine angle triton tumor despite stereotactic radiosurgery. Case report J Neurosurg 89:653-658. https://doi.org/10.3171/jns.1998.89.4.0653

20. Demetriades AK, Saunders N, Rose P, Fisher C, Rowe J, Tranter R, Hardwidge C (2010) Malignant transformation of acoustic neuroma/vestibular schwannoma 10 years after gamma knife stereotactic radiosurgery. Skull Base 20:381-387. https://doi.org/10. 1055/s-0030-1253576

21. Frischer JM, Gruber E, Schoffmann V, Ertl A, Hoftberger R, Mallouhi A, Wolfsberger S, Arnoldner C, Eisner W, Knosp E, Kitz K, Gatterbauer B (2018) Long-term outcome after Gamma Knife radiosurgery for acoustic neuroma of all Koos grades: a single-center study. J Neurosurg 1-10. https://doi.org/10.3171/ 2017.8.JNS171281

22. Hanabusa K, Morikawa A, Murata T, Taki W (2001) Acoustic neuroma with malignant transformation. Case report J Neurosurg 95:518-521. https://doi.org/10.3171/jns.2001.95.3.0518

23. Hasegawa T, Fujitani S, Katsumata S, Kida Y, Yoshimoto M, Koike J (2005) Stereotactic radiosurgery for vestibular schwannomas: analysis of 317 patients followed more than 5 years. Neurosurgery 57:257-265. https://doi.org/10.1227/01.neu. 0000166542.00512 .84 (discussion 257-265)

24. Ho SY, Kveton JF (2002) Rapid growth of acoustic neuromas after stereotactic radiotherapy in type 2 neurofibromatosis. Ear Nose Throat J 81:831-833

25. Kubo O, Chernov M, Izawa M, Hayashi M, Muragaki Y, Maruyama T, Hori T, Takakura K (2005) Malignant progression of benign brain tumors after gamma knife radiosurgery: is it really caused by irradiation? Minim Invasive Neurosurg 48:334-339. https://doi.org/10.1055/s-2005-915632

26. Kuzmik GA, Michaelides EM, Chiang VL, Nonaka Y, Fukushima T, Vortmeyer AO, Bulsara KR (2013) Rapidly progressive epithelioid malignant peripheral nerve sheath tumor of the vestibular nerve. Otol Neurotol 34:1739-1742. https://doi.org/ 10.1097/MAO.0b013e31829ab8be

27. Markou K, Eimer S, Perret C, Huchet A, Goudakos J, Liguoro D, Franco-Vidal V, Maire JP, Darrouzet V (2012) Unique case of malignant transformation of a vestibular schwannoma after fractionated radiotherapy. Am J Otolaryngol 33:168-173. https://doi.org/10.1016/j.amjoto.2011.02.006

28. McEvoy AW, Kitchen ND (2003) Rapid enlargement of a vestibular schwannoma following gamma knife treatment. Minim Invasive Neurosurg 46:254-256. https://doi.org/10. 1055/s-2003-42347

29. Milligan BD, Pollock BE, Foote RL, Link MJ (2012) Long-term tumor control and cranial nerve outcomes following gamma knife surgery for larger-volume vestibular schwannomas. J Neurosurg 116:598-604. https://doi.org/10.3171/2011.11.JNS11811

30. Muracciole X, Cowen D, Regis J (2004) Radiosurgery and brain radio-induced carcinogenesis: update. Neurochirurgie 50:414-420

31. Noren G (1998) Long-term complications following gamma knife radiosurgery of vestibular schwannomas. Stereotact Funct Neurosurg 70(Suppl 1):65-73. https://doi.org/10.1159/000056408

32. Peker HO, Gok H, Altay T (2019) Malignant Transformation of Vestibular Schwannoma after Stereotactic Radiosurgery. World Neurosurg. https://doi.org/10.1016/j.wneu.2018.12.149

33. Pollock BE, Link MJ, Stafford SL, Parney IF, Garces YI, Foote RL (2017) The Risk of Radiation-Induced Tumors or Malignant Transformation After Single-Fraction Intracranial Radiosurgery: Results Based on a 25-Year Experience. Int J Radiat Oncol Biol Phys 97:919-923. https://doi.org/10.1016/j.ijrobp.2017.01.004

34. Puataweepong P, Janwityanujit T, Larbcharoensub N, Dhanachai M (2012) Radiation-induced peripheral malignant nerve sheath tumor arising from vestibular schwannoma after linac-based 
stereotactic radiation therapy: a case report and review of literatures. Case Rep Med 2012:648191. https://doi.org/10.1155/2012/ 648191

35. Schmitt WR, Carlson ML, Giannini C, Driscoll CL, Link MJ (2011) Radiation-induced sarcoma in a large vestibular schwannoma following stereotactic radiosurgery: case report. Neurosurgery 68:E840-846. https://doi.org/10.1227/NEU.0b013e3182 0780b1 (discussion E846)

36. Se YB, Kim DG, Park SH, Chung HT (2017) Radiation-induced osteosarcoma after Gamma Knife surgery for vestibular schwannoma: a case report and literature review. Acta Neurochir (Wien) 159:385-391. https://doi.org/10.1007/s00701-016-3031-x

37. Shin M, Ueki K, Kurita H, Kirino T (2002) Malignant transformation of a vestibular schwannoma after gamma knife radiosurgery. Lancet 360:309-310. https://doi.org/10.1016/S0140-6736(02) 09521-1

38. Simmermacher S, Vordermark D, Kegel T, Strauss C (2017) Malignization of a vestibular schwannoma 13 years after radiation therapy. HNO 65:153-157. https://doi.org/10.1007/ s00106-017-0362-8

39. Tanbouzi Husseini S, Piccirillo E, Taibah A, Paties CT, Rizzoli R, Sanna M (2011) Malignancy in vestibular schwannoma after stereotactic radiotherapy: a case report and review of the literature. Laryngoscope 121:923-928. https://doi.org/10.1002/lary.21448

40. Thomsen J, Mirz F, Wetke R, Astrup J, Bojsen-Moller M, Nielsen E (2000) Intracranial sarcoma in a patient with neurofibromatosis type 2 treated with gamma knife radiosurgery for vestibular schwannoma. Am J Otol 21:364-370. https://doi.org/10.1016/ s0196-0709(00)80046-0

41. Tish S, Ross L, Habboub G, Roser F, Recinos PF (2019) Malignant triton tumor diagnosed twelve years after radiosurgically treated vestibular schwannoma. Clin Neurol Neurosurg 183:105367. https://doi.org/10.1016/j.clineuro.2019.05.015

42. Wilkinson JS, Reid H, Armstrong GR (2004) Malignant transformation of a recurrent vestibular schwannoma. J Clin Pathol 57:109-110. https://doi.org/10.1136/jcp.57.1.109

43. Yanamadala V, Williamson RW, Fusco DJ, Eschbacher J, Weisskopf P, Porter RW (2013) Malignant transformation of a vestibular schwannoma after gamma knife radiosurgery. World Neurosurg 79(593):e591-598. https://doi.org/10.1016/j.wneu.2012.03.016

44. Yang T, Rockhill J, Born DE, Sekhar LN (2010) A case of highgrade undifferentiated sarcoma after surgical resection and stereotactic radiosurgery of a vestibular schwannoma. Skull Base 20:179-183. https://doi.org/10.1055/s-0029-1242195

45. Behling F, Suhm E, Ries V, Goncalves VM, Tabatabai G, Tatagiba M, Schittenhelm J (2021) COX2 expression is associated with preoperative tumor volume but not with volumetric tumor growth in vestibular schwannoma. Neurol Res Pract 3:11. https://doi.org/ 10.1186/s42466-021-00111-6

46. Lu VM, Marek T, Gilder HE, Puffer RC, Raghunathan A, Spinner RJ, Daniels DJ (2019) H3K27 trimethylation loss in malignant peripheral nerve sheath tumor: a systematic review and metaanalysis with diagnostic implications. J Neurooncol 144:433-443. https://doi.org/10.1007/s11060-019-03247-3

47. Prieto-Granada CN, Wiesner T, Messina JL, Jungbluth AA, Chi P, Antonescu CR (2016) Loss of H3K27me3 Expression Is a Highly Sensitive Marker for Sporadic and Radiation-induced MPNST. Am J Surg Pathol 40:479-489. https://doi.org/10.1097/PAS.00000 00000000564

48. Rohrich M, Koelsche C, Schrimpf D, Capper D, Sahm F, Kratz A, Reuss J, Hovestadt V, Jones DT, Bewerunge-Hudler M, Becker A, Weis J, Mawrin C, Mittelbronn M, Perry A, Mautner VF, Mechtersheimer G, Hartmann C, Okuducu AF, Arp M, Seiz-Rosenhagen M, Hanggi D, Heim S, Paulus W, Schittenhelm J, Ahmadi R, Herold-Mende C, Unterberg A, Pfister SM, von Deimling A, Reuss DE (2016) Methylation-based classification of benign and malignant peripheral nerve sheath tumors. Acta Neuropathol 131:877-887. https://doi.org/10.1007/s00401-016-1540-6

49. Agnihotri S, Jalali S, Wilson MR, Danesh A, Li M, Klironomos G, Krieger JR, Mansouri A, Khan O, Mamatjan Y, Landon-Brace N, Tung T, Dowar M, Li T, Bruce JP, Burrell KE, Tonge PD, Alamsahebpour A, Krischek B, Agarwalla PK, Bi WL, Dunn IF, Beroukhim R, Fehlings MG, Bril V, Pagnotta SM, Iavarone A, Pugh TJ, Aldape KD, Zadeh G (2016) The genomic landscape of schwannoma. Nat Genet 48:1339-1348. https://doi.org/10.1038/ ng. 3688

50. Mito JK, Qian X, Doyle LA, Hornick JL, Jo VY (2017) Role of Histone H3K27 Trimethylation Loss as a Marker for Malignant Peripheral Nerve Sheath Tumor in Fine-Needle Aspiration and Small Biopsy Specimens. Am J Clin Pathol 148:179-189. https:// doi.org/10.1093/ajcp/aqx060

51. Miettinen MM, Antonescu CR, Fletcher CDM, Kim A, Lazar AJ, Quezado MM, Reilly KM, Stemmer-Rachamimov A, Stewart DR, Viskochil D, Widemann B, Perry A (2017) Histopathologic evaluation of atypical neurofibromatous tumors and their transformation into malignant peripheral nerve sheath tumor in patients with neurofibromatosis 1-a consensus overview. Hum Pathol 67:1-10. https://doi.org/10.1016/j.humpath.2017.05.010

Publisher's note Springer Nature remains neutral with regard to jurisdictional claims in published maps and institutional affiliations. 